\title{
Elaboration and Characterization of Apple Nectars Supplemented with Araçá-boi (Eugenia stipitata Mac Vaugh-Myrtaceae)
}

\author{
Tatiana Ferrari Baldini ${ }^{1}$, Iramaia Angélica Neri-Numa ${ }^{1}$, Celio Kersul do Sacramento ${ }^{3}$, \\ Marcio Schmiele ${ }^{4}$, Helena Maria Andre Bolini ${ }^{2}$, Glaucia Maria Pastore ${ }^{1}$ and \\ Juliano Lemos Bicas ${ }^{1, *}$
}

1 Department of Food Science, University of Campinas, Rua Monteiro Lobato, 80, 13083-862 Campinas, SP, Brazil; tatifbaldini@gmail.com (T.F.B.); iramaianuma@gmail.com (I.A.N.-N.); glaupast@fea.unicamp.br (G.M.P.)

2 Department of Food and Nutrition, University of Campinas, Rua Monteiro Lobato, 80, 13083-862 Campinas, SP, Brazil; hellini@unicamp.br

3 Department $\mathrm{f}$ Agrarian and Environmental Sciences, State University of Santa Cruz, Rodovia Ilhéus Itabuna Km 16, 45650-000 Ilhéus, BA, Brazil; kersul@uesc.br

4 Institute of Science and Technology, Federal University of Jequitinhonha and Mucury Valleys, Rodovia MGT-367-Km 583, n 5000, 39100-000 Diamantina, MG, Brazil; marcio.sc@ict.ufvjm.edu.br

* Correspondence: jlbicas@gmail.com; Tel.: +55-19-3521-0065; Fax: +55-19-3521-3887

Academic Editor: Danyang Ying

Received: 20 October 2017; Accepted: 23 November 2017; Published: 5 December 2017

\begin{abstract}
Fruits and vegetables are known as sources of nutritionally important phytochemicals, such as phenolic compounds, and Brazilian biodiversity may be hiding many underexplored fruits with potential health benefits. In this study, we formulated a fruit-based beverage by supplementing known amounts of freeze-dried araçá-boi (Eugenia stipitata) (FD) to a commercial apple nectar in order to evaluate the impact in terms of nutritional (level of phenolic compounds, flavonoids and antioxidant capacity) and sensory parameters. The best acceptance was evidenced for the apple nectar supplemented with $1 \mathrm{~g} / \mathrm{L}$ of FD, while no statistically significant changes were obtained for non-supplemented apple nectar and apple nectar supplemented with 5 or $10 \mathrm{~g} / \mathrm{L}$ FD. Lower acceptances for apple nectars supplemented with 15, 20 or $30 \mathrm{~g} / \mathrm{L}$ FD were suggested to be caused by an increase in acidity. In general, total phenols, flavonoids and antioxidant capacity (DPPH, TEAC and ORAC) increased with the supplementation level, although not always a statistically significant difference was observed. When compared to control (non-supplemented), the apple nectar supplemented with $10 \mathrm{~g} / \mathrm{L}$ FD presented a significant increase in total phenols, flavonoids and antioxidant capacity (except for ORAC assay), and therefore this level of supplementation was considered ideal, considering both nutritional and sensory properties.
\end{abstract}

Keywords: antioxidant; Eugenia stipitata; functional beverage; phenolic compounds

\section{Introduction}

Consumption of fruits and vegetables is no longer merely a result of taste and personal preference, but it has been associated with the adoption of healthier lifestyles due the presence of essential nutrients and secondary phytochemical compounds that are frequently associated to the protection against several pathophysiological processes [1-3]. Many studies have focused on the antioxidant capacity of plant-derived food, especially the fruits with high phenolic content, in order to understand their role in the health benefits, such as the prevention of degenerative diseases, central nervous system disorders, cancer as well as the aging process, amongst others $[4,5]$. 
For these reasons, much effort has been made to characterize the phytochemical contents of tropical fruits that, besides presenting a great species diversity with characteristic flavors, attractive colors, and special scents, are considered stronger candidates for screening of antioxidant properties $[2,4,6]$. In this context, Brazil offers a wide variety of native fruits with nutritional qualities and health claims that are still little known by consumers. Thus, considering their exotic character and potential health benefits, the introduction of these fruits on food chains could represent an important economic activity not only for local but also to the growing international markets [7-10].

The beverage industry is continuously innovating their portfolio, including the combination of nutritionally rich fruits with sensory attractive juices to get improved acceptability and price. This has led to the creation of new market niches with the development of nectars, ready-to-serve beverages, and others [11,12]. Therefore, due to the economic potential and social importance of Brazilian native fruits, several scientific research institutions have tried to reinforce the agroindustrial development by developing commercial production orchards as well as technological capabilities of industrial processing of these fruits [13].

Eugenia stipitata Mac Vaugh (Myrtaceae), known as araçá-boi, is one such Brazilian native fruit, found in the western Amazon and the Guianas. It is an edible globe-shaped berry approximately $12 \mathrm{~cm}$ in diameter and weighing around $95 \mathrm{~g}$, characterized by an intense canary yellow color with a delicate peel and a white soft mucilaginous pulp $[4,14,15]$. Despite being highly aromatic, this fruit is quite sour. Thus, it is not commonly consumed in natura, but its industrial processing could represent an attractive alternative to formulating juices, ice creams, jams and nectars $[4,14]$.

Regarding their biological properties and phytochemical composition, E. stiptata is rich in terpenes, volatile compounds, soluble sugars, fibers, vitamin C and carotenoids, mainly lutein. Araçá-boi also has a considerable antioxidant capacity [16-19]. In addition, Gonçalves, Lajolo and Genovese (2010) [20] also reported high contents of glycosylated quercetin derivatives in araçá-boi, which resulted in an antidiabetic potential by inhibiting both $\alpha$-glucosidase and $\alpha$-amylase enzymes. In the same way, the extract of E. stipitata fruit showed good antioxidant capacity and a total phenolic amount rated as medium. Moreover, antimutagenic and antigenotoxic activities were observed at $300 \mathrm{mg}$ of extract/kg bw [9].

Therefore, the present work aimed to supplement commercial apple nectar with freeze-dried araçá-boi (FD) and to evaluate the sensory profile and the antioxidant potential of such a beverage, in order to assess the use of this Brazilian native fruit as a functional ingredient for enriching and adding value to beverages.

\section{Materials and Methods}

\subsection{Chemicals}

The standards of gallic acid, (+)-catechin, and the reagents 2,2-diphenyl-1-picrylhydrazil (DPPH), 6-hydroxy-2,5,7,8-tetramethylchromane-2-carboxylic acid (Trolox), 2,20-azobis(2methylamidinopropane)-dihydrochloride (AAPH) and sodium fluorescein were purchased from Sigma-Aldrich Co. (St. Louis, MO, USA). All other chemicals and solvents in this study were of analytical grade.

\subsection{Plant Material and Nectar Formulation}

Ripe araçá-boi (Eugenia stipitata) fruits were collected during summer (January 2014) at "Kamui Farm" in Ituberá city (Brazil), on coordinate geographic $13^{\circ} 44^{\prime \prime} \mathrm{S} 39^{\circ} 9^{\prime \prime} \mathrm{W}$. The botanical identification and the exsicate (access number 55,875) were deposited at the Herbarium-UEC of Agronomic Institute of Campinas, State of São Paulo, Brazil.

The edible portion of the pre-washed fruit was processed in a home juicer (Philips Walita, Vito RI 6728, Barueri, SP, Brazil) and then freeze-dried for $72 \mathrm{~h}$ (Terroni Equipamentos Científicos, LS 3000, São Carlos, SP, Brazil). Subsequently, the freeze-dried samples were powdered using a ball 
mill (Brabender Technologie, Quadrumat Senior, Duisburg, Germany), sieved in 60 to $100 \mathrm{MESH}$, conditioned in polyethylene bags, packed under vacuum and kept at $-18{ }^{\circ} \mathrm{C}$ until use.

Apple nectars supplemented with FD were prepared by mixing a commercial apple nectar and FD in different proportions (see Section 2.4). The supplemented apple nectars were characterized in terms of chemical, physicochemical and sensory properties (Sections 2.3-2.6).

\subsection{Centesimal Composition and Physicochemical Characterization}

The methods of the Association of Official Analytical Chemists [21] were used to determine moisture content (AOAC 920.151), ash (AOAC 940.26), protein (AOAC 920.152), soluble and insoluble fibers (AOAC 985.29) and lipids (AOAC 948.22). Digestible carbohydrates were calculated as the difference to 100\% [22]. Total soluble solids (TSS) (AOAC 932.12), $\mathrm{pH}$ (AOAC 981.12) and titratable acidity (AOAC 942.15) were determined according to AOAC (2012). Vitamin C was determined according to method 365/IV of Instituto Adolf Lutz [23].

\subsection{Sensory Analysis}

Sensory analysis assays were previously approved by the Unicamp Research Ethics Committee (1.179.209). The tests done are described in the sequence.

\subsubsection{Difference-from-Control Test}

Difference-from-control test was performed according to Meilgaard et al. (2004) [24]. Twenty six consumers of tropical fruit nectar participated on the test. Each one of the tasters received a standard (control) sample (non-supplemented), four codified samples (apple nectar supplemented with 5, 10 and $20 \mathrm{~g} / \mathrm{L} \mathrm{FD})$ and the ballot. Tasters received $20 \mathrm{~mL}$ of each sample $\left(4^{\circ} \mathrm{C}\right)$ in $50 \mathrm{~mL}$ plastic cups. Samples were presented coded with three digit numbers, in balanced complete block design [25]. They were asked about the global sensory difference between the apple nectar (control) and the codified samples [26].

The collected data from difference-from-control test were analyzed by ANOVA and Dunnett test and the data from acceptance tests were analyzed by ANOVA and Tukey's test $(p<0.05)$.

\subsubsection{Acceptance Test}

Acceptance test was performed according to Stone, Bleibaum and Thomas (2012) [27], carried out by 112 consumers of nectars. Each consumer received six codified samples, one standard sample (non-supplemented apple nectar) and five samples of the apple nectar supplemented with FD in the concentrations of 1, 5, 10, 15 and $30 \mathrm{~g} / \mathrm{L}$. Samples were presented in a monadic way, in balanced complete block design [25] and coded with three digit numbers. Consumers received $20 \mathrm{~mL}$ of each sample $\left(4^{\circ} \mathrm{C}\right)$ in $50 \mathrm{~mL}$ plastic cups and a specific ballot. On the ballot, the consumers were asked about the acceptance of the samples regarding the following parameters: appearance, color, texture, flavor and global impression. It was used a 9-cm unstructured line scale [28] for the evaluation of each parameter. Additionally, tasters were also asked about purchase intentions, measured through a structured 5 points scale going from " $1=$ would certainly not buy it" to " $5=$ would certainly buy it" [24].

\subsection{Determination of Phenolic Compounds and Flavonoids}

Total phenolics (TP) were determined using the Folin-Ciocalteu method [29]. FD was dissolved in methanol $50 \%$ to get a $3 \mathrm{mg} / \mathrm{mL}$ solution which was then diluted in order to obtain different concentrations $(0.2-3.0 \mathrm{mg} / \mathrm{mL})$. Non-supplemented and supplemented apple nectars were dissolved in methanol $50 \%$ to get $160 \mathrm{mg} / \mathrm{mL}$ solutions and then diluted in order to obtain different concentrations (20-160 mg/mL). A $60 \mu \mathrm{L}$ aliquot of homogenate of each sample was mixed with $300 \mu \mathrm{L}$ of 10 -fold diluted Folin-Ciocalteau reagent and $240 \mu \mathrm{L}$ of $7.5 \%$ sodium carbonate solution. After $5 \mathrm{~min}$ at $50{ }^{\circ} \mathrm{C}$, absorbance at $750 \mathrm{~nm}$ was read in spectrophotometer (DU-640 ${ }^{\mathrm{TM}}$, Beckman 
Coulter Inc., Brea, CA, USA). Standard concentrations of gallic acid $(2.5-60 \mu \mathrm{mol} / \mathrm{L})$ were used to prepare a calibration curve $\left(\mathrm{Abs}_{750}=0.0271\right.$.Gallic acid $\left.[\mu \mathrm{mol} / \mathrm{L}]+0.0303\right)$. Determinations were carried out in triplicate.

Flavonoids content was measured by a colorimetric assay described by Zhishen, Mengcheng and Jianming (1999) [30]. A FD extract was prepared by dissolving FD in water (50 mg/mL), followed by ultrasonic bath at $10{ }^{\circ} \mathrm{C} / 30 \mathrm{~min}$. This extract was centrifuged $\left(5000 \mathrm{rpm} / 5 \mathrm{~min}\right.$ at $\left.5{ }^{\circ} \mathrm{C}\right)$ and used to prepare a series dilution $(6-45 \mathrm{mg} / \mathrm{mL})$. Extracts of non-supplemented and supplemented apple nectars were dissolved in water $(600 \mathrm{mg} / \mathrm{mL})$, followed by ultrasonic bath at $10^{\circ} \mathrm{C} / 30 \mathrm{~min}$. The extracts were centrifuged $\left(5000 \mathrm{rpm} / 5 \mathrm{~min}\right.$ at $\left.5{ }^{\circ} \mathrm{C}\right)$ and used to prepare a series dilution $(75-525 \mathrm{mg} / \mathrm{mL})$. The colorimetric reaction consisted of a mixture of $240 \mu \mathrm{L}$ water, $60 \mu \mathrm{L}$ sample and $18 \mu \mathrm{L} \mathrm{NaNO}{ }_{2} \%$. After $5 \mathrm{~min}, 18 \mu \mathrm{L}$ of $\mathrm{AlCl}_{3} 10 \%$ was added. After $6 \mathrm{~min}, 120 \mu \mathrm{L} \mathrm{NaOH} 1 \mathrm{M}$ and $144 \mu \mathrm{L}$ of water was added to the mixture. The absorbance of the resulting solution was read at $510 \mathrm{~nm}$ in spectrophotometer (DU-640 ${ }^{\mathrm{TM}}$, Beckman Coulter Inc., Brea, CA, USA). A calibration curve was done with standard catechin solution $(50-500 \mu \mathrm{mol} / \mathrm{L})\left(\mathrm{Abs}_{510}=0.000943\right.$.Catechin $\left.[\mu \mathrm{mol} / \mathrm{L}]+0.03892\right)$. Determination of TP and flavonoids were carried out in triplicate.

\subsection{Antioxidant Capacity}

\subsection{1. $\mathrm{DPPH}^{\bullet}$ Scavenging Assay}

Free radical-scavenging capacity was measured using a method proposed by Roesler (2007) [29] and Scherer and Godoy (2009) [31]. Experiments were performed on freshly prepared methanolic solutions of DPPH $(0.004 \% w / v)$. In brief, $100 \mu \mathrm{L}$ of FD, non-supplemented and supplemented apple nectars solutions, all prepared in methanol PA in different concentrations $(0.25-3.5 \mathrm{mg} / \mathrm{mL}$ for FD and $10-140 \mathrm{mg} / \mathrm{mL}$ for non-supplemented and supplemented apple nectars), were mixed with $500 \mu \mathrm{L}$ of DPPH solution in microtubes. After $30 \mathrm{~min}$, the absorbance was read at $517 \mathrm{~nm}$ in spectrophotometer (DU-640 ${ }^{\mathrm{TM}}$, Beckman Coulter Inc., Brea, CA, USA). Trolox was used as a standard using a calibration curve $(25-200 \mu \mathrm{mol} / \mathrm{L})(\%$ Inhibition $=0.6063$.Trolox $[\mu \mathrm{mol} / \mathrm{L}]-6.1592)$. This assay was performed in triplicate.

\subsubsection{Trolox Equivalent Antioxidant Capacity (TEAC)}

Antioxidant capacity was measured by the TEAC method described by Re et al. (1999) [32]. Briefly, the radical cation ABTS' was prepared $12-16 \mathrm{~h}$ prior to the assay. Radical production occurred by mixing an aqueous solution of $7 \mathrm{mM}$ ABTS' and $140 \mathrm{mM}$ potassium persulfate, which was then diluted with water until absorbance reached a value of $0.70 \pm 0.02$ at $734 \mathrm{~nm}$. FD, non-supplemented and supplemented apple nectars solutions were prepared in ethanol in different concentrations $(0.05-1.20 \mathrm{mg} / \mathrm{mL}$ for FD and $5-70 \mathrm{mg} / \mathrm{mL}$ for the nectars). The reaction system was composed of 100 $\mu \mathrm{L}$ of sample and $500 \mu \mathrm{L}$ of $\mathrm{ABTS}^{\bullet+}$ solution, followed by 6 minutes incubation at room temperature. The absorbance values were measured at $734 \mathrm{~nm}$ in a spectrophotometer (DU 640 ${ }^{\mathrm{TM}}$, Beckman-Coulter, Brea, CA, USA). A calibration curve was plotted of absorbance reduction and concentration of Trolox $(5-120 \mu \mathrm{M})(\%$ Inhibition $=0.7525$.Trolox $[\mu \mathrm{mol} / \mathrm{L}]-0.3657)$. This assay was performed in triplicate.

\subsubsection{Oxygen Radical Absorbance Capacity (ORAC) Assay}

The ORAC assay followed the procedure described by Leite et al. (2011) [33]. FD, non-supplemented and supplemented apple nectars solutions were prepared in $75 \mathrm{mM}$ phosphate buffer ( $\mathrm{pH}$ 7.4) in different concentrations $(0.05-1.20 \mathrm{mg} / \mathrm{mL}$ for FD and $5-70 \mathrm{mg} / \mathrm{mL}$ for the nectars). Sample $(20 \mu \mathrm{L})$ and fluorescein $(120 \mu \mathrm{L} ; 70 \mu \mathrm{M}$ in final concentration) solutions were mixed in one of the 96 wells of a black microplate. Then, $60 \mu \mathrm{L}$ of an AAPH solution (final concentration $12 \mathrm{mM}$ ) was added and fluorescence was checked every cycle of $60 \mathrm{~s}$ for 80 cycles, with temperature kept at $37^{\circ} \mathrm{C}$, using a NovoStar Microplate reader (BMG Labtech, Ortenberg, Germany) with fluorescence filters (excitation, 
$\lambda 485 \mathrm{~nm}$; emission $\lambda 520 \mathrm{~nm}$ ). The result was calculated using the differences of areas under fluorescein decay curves between the blank (net AUC) and sample. AUC and net AUC were calculated as follows:

$$
\mathrm{AUC}=1+\Sigma f_{i} / f_{0}
$$

In which $f_{0}$ is the initial fluorescence $(\mathrm{t}=0)$ and $f_{i}$ is the fluorescence obtained at $\mathrm{t}=\mathrm{i}$ (minutes).

$$
\text { Net } \mathrm{AUC}=\mathrm{AUC}_{\text {sample }}-\mathrm{AUC}_{\text {blank }}
$$

Net AUC was plotted against sample concentration and results were compared to the standard curve (Net AUC versus Trolox concentration) (Net AUC $=0.03357$.Trolox $[\mu \mathrm{mol} / \mathrm{L}]+6.4752$ ). The equivalence of Trolox was given by the angular coefficient of Trolox curve concentration $(\mu \mathrm{mol} / \mathrm{L})$ versus sample concentration $(\mu \mathrm{mol} / \mathrm{L})$. This assay was performed in three independent replicates.

\section{Results}

\subsection{Centesimal Composition of Araçá-boi}

The material used to supplement the apple nectar, a freeze-dried araçá-boi (FD), was characterized in terms of centesimal composition. Based on the yield of FD $(13.15 \mathrm{~g} / 100 \mathrm{~g})$, the composition of araçá-boi was calculated in wet weight and dry weight basis (Table 1).

Table 1. Centesimal composition of freeze-dried araçá-boi (FD) and the calculated composition of araçá-boi in wet or dry weight. Three replications were performed and data are presented as

\begin{tabular}{|c|c|c|c|}
\hline Parameter & FD $^{1}$ & Composition $(w w)^{2}$ & Composition (dw) ${ }^{3}$ \\
\hline Moisture & $8.21 \pm 0.21$ & $87.93 \pm 0.46$ & 0 \\
\hline Ash & $1.72 \pm 0.02$ & $0.23 \pm 0.01$ & $1.87 \pm 0.01$ \\
\hline Lipids & $1.21 \pm 0.05$ & $0.16 \pm 0.01$ & $1.32 \pm 0.05$ \\
\hline Proteins & $5.31 \pm 0.08$ & $0.70 \pm 0.03$ & $5.79 \pm 0.07$ \\
\hline Digestible carbohydrates & $46.96 \pm 2.73$ & $6.17 \pm 0.84$ & $51.16 \pm 1.53$ \\
\hline Total fibers & $36.59 \pm 1.37$ & $4.81 \pm 0.33$ & $39.86 \pm 1.40$ \\
\hline Soluble fibers & $9.84 \pm 1.96$ & $1.29 \pm 0.52$ & $10.72 \pm 1.51$ \\
\hline Insoluble fibers & $26.75 \pm 0.59$ & $3.52 \pm 0.19$ & $29.14 \pm 0.57$ \\
\hline
\end{tabular}
mean \pm standard deviation.

1 values expressed as percentage $(\%, w / w) ;{ }^{2}$ values expressed as percentage $(\%$, wet weight), calculated considering the moisture of FD the yield of FD, i.e., $100 \mathrm{~g}$ of fresh fruit result in $13.15 \mathrm{~g}$ of FD; ${ }^{3}$ values expressed as percentage (\%, dry weight), calculated excluding the moisture content of FD.

\subsection{Sensory Analysis}

The strategy considered in this study was to first analyze if consumers would perceive the difference of non-supplemented nectars and nectars supplemented with $5 \mathrm{~g} / \mathrm{L}, 10 \mathrm{~g} / \mathrm{L}$ or $20 \mathrm{~g} / \mathrm{L}$ of FD through a difference-from-control test In the sequence, an Acceptance and Purchase Intention test would be used to indicate which are these differences and whether they are desirable or not.

According to the results (Table 2), the analysts could detect differences $(p<0.05)$ in all supplemented apple nectars. Therefore, an acceptance test using hedonic scale was performed to check which these differences were and to evaluate which apple supplemented nectar would be best accepted by the consumers. The difference-from-control test was also important to guide the choice of which concentrations to be tested in the acceptance test.

The results presented in Table 3 indicate that N1FD was the sample presenting the best acceptance in relation to flavor and overall impression. This sample also presented the best acceptance in terms of global appearance, color and texture, although with no significant differences with regard to samples N0FD to N10FD, N5FD to N10FD and N0FD to N5FD, respectively. N30FD, on the other hand, showed the lowers acceptance averages for all parameters evaluated, probably influenced by its high acidity 
(Table 1). There were no statistically significant differences between N0FD and nectars supplemented with up to $10 \mathrm{~g} / \mathrm{L}$ of FD, except for sample N1FD, as cited above.

Table 2. Results of the difference-from-control test.

\begin{tabular}{cc}
\hline Comparison of Samples & Difference between Means \\
\hline N20FD-N0FD & $5.85 \pm 2.59^{*}$ \\
N10FD-NOFD & $4.19 \pm 3.16^{*}$ \\
N5FD-N0FD & $2.31 \pm 3.57^{*}$ \\
\hline
\end{tabular}

* Means with statistic difference $(p<0.05)$ according to Dunnett's test.

Table 3. Average * values for the sensory parameters evaluated in the acceptance test.

\begin{tabular}{|c|c|c|c|c|c|}
\hline Sample & General Appearance & Color & Flavor & Texture & Global Impression \\
\hline NOFD & $5.7 \pm 1.8^{\mathrm{ab}}$ & $5.5 \pm 1.9^{b}$ & $5.1 \pm 2.3^{b c}$ & $5.9 \pm 2.1^{\mathrm{ab}}$ & $5.4 \pm 1.97 \mathrm{bc}$ \\
\hline N1FD & $6.1^{\mathrm{a}} \pm 1.6$ & $6.0 \pm 1.6^{\mathrm{a}}$ & $6.1 \pm 1.8^{a}$ & $6.4 \pm 1.7^{\mathrm{a}}$ & $6.3 \pm 1.50^{\mathrm{a}}$ \\
\hline N5FD & $5.9 \pm 1.8^{\mathrm{ab}}$ & $5.8 \pm 1.8^{\mathrm{ab}}$ & $5.4 \pm 2.2^{b}$ & $5.9 \pm 1.8^{\mathrm{ab}}$ & $5.7 \pm 1.81^{b}$ \\
\hline N10FD & $5.6 \pm 1.8^{\mathrm{ab}}$ & $5.5 \pm 1.8^{a b}$ & $4.5 \pm 2.3^{\mathrm{cd}}$ & $5.4 \pm 2.2^{b c}$ & $5.0 \pm 2.0^{\mathrm{cd}}$ \\
\hline N15FD & $5.4 \pm 2.0^{b}$ & $5.4 \pm 2.0^{b}$ & $3.9 \pm 2.4^{\mathrm{d}}$ & $5.0 \pm 2.2^{c}$ & $4.5 \pm 2.1^{\mathrm{d}}$ \\
\hline N30FD & $4.3 \pm 2.4^{\mathrm{c}}$ & $4.4 \pm 2.3^{c}$ & $2.5 \pm 2.3^{\mathrm{e}}$ & $3.6 \pm 2.4^{\mathrm{d}}$ & $3.0 \pm 2.2^{\mathrm{e}}$ \\
\hline
\end{tabular}

${ }^{*}$ Means with same letters the same column do not differ statistically $(p<0.05)$ according to Tukey's test.

In a reflex of such results, N1FD was the sample presenting the best profile of Purchase Intention (higher scores for "probably would buy it" or "definitely would buy it"), while N30FD showed the poorest behavior in terms of Purchase Intention (higher scores for "definitely would not buy $i t^{\prime \prime}$ and lower scores for "probably would buy it" or "certainly would buy it") (Figure 1). N5FD or N10FD presented a profile of Purchase Intention close to that of the standard product (NOFD), i.e., the "unfavorable" deviations (increase in scores for "definitely would not buy it", "probably would not buy it" and "I have doubts if I would buy it"; or decrease in scores for "probably would buy it" and "definitely would buy it"), varied from four (N5FD) to six (N10FD) percentage points, while the "favorable" deviations (decrease in scores for "definitely would not buy it", "probably would not buy it" and "I have doubts if I would buy it"; or increase in scores for "probably would buy it" and "definitely would buy it"), reached 11 percentage points (N5FD) (Figure 1).

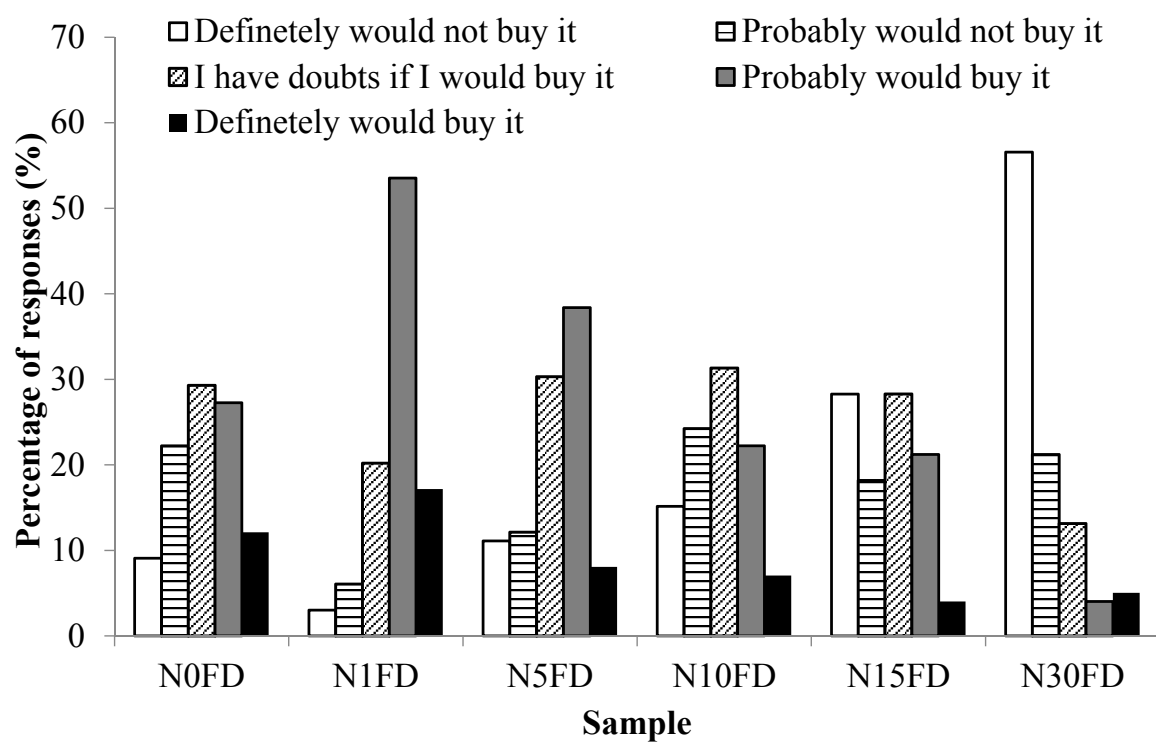

Figure 1. Purchase Intention for non-supplemented apple nectar (NOFD) or supplemented with $1 \mathrm{~g} / \mathrm{L}$ (N1FD), 5 g/L (N5FD), 10 g/L (N10FD), 15 g/L (N15FD) or 30 g/L (N30FD) of freeze-dried araçá-boi. 


\subsection{Physicochemical Characterization}

The results for $\mathrm{pH}$, titratable acidity, total soluble solids (TSS) and ascorbic acid content of the apple nectars are presented in Table 4.

Table 4. Physicochemical parameters * of non-supplemented apple nectar (NOFD), apple nectar supplemented with $1 \mathrm{~g} / \mathrm{L}$ (N1FD), 5 g/L (N5FD), $10 \mathrm{~g} / \mathrm{L}$ (N10FD), 15 g/L (N15FD) or 30 g/L (N30FD) of freeze-dried araçá-boi and reconstituted freeze-dried araçá-boi. Three replications were performed and data are presented as mean \pm standard deviation.

\begin{tabular}{cccccc}
\hline Sample & $\mathbf{p H}$ & Acidity $^{\mathbf{1}}$ & TSS $^{\mathbf{2}}$ & TSS/Acidity & Ascorbic Acid $^{\mathbf{3}^{3}}$ \\
\hline N0FD & $3.15 \pm 0.03^{\mathrm{a}}$ & $0.24 \pm 0.02^{\mathrm{d}}$ & $9.85 \pm 0.60^{\mathrm{c}}$ & $41.04 \pm 5.95$ & $24.11 \pm 0.09$ \\
N1FD & $3.07 \pm 0.02^{\mathrm{b}}$ & $0.27 \pm 0.01^{\mathrm{d}}$ & $10.36 \pm 0.23^{\mathrm{bc}}$ & $38.37 \pm 2.28$ & $24.14 \pm 0.10^{4}$ \\
N5FD & $2.98 \pm 0.02^{\mathrm{c}}$ & $0.36 \pm 0.01^{\mathrm{cd}}$ & $10.56 \pm 0.05^{\mathrm{b}}$ & $29.33 \pm 0.95$ & $24.25 \pm 0.11^{4}$ \\
N10FD & $2.92 \pm 0.03^{\mathrm{d}}$ & $0.48 \pm 0.01^{\mathrm{cb}}$ & $10.88 \pm 0.25^{\mathrm{b}}$ & $22.67 \pm 1.00$ & $24.39 \pm 0.13^{4}$ \\
N15FD & $2.88 \pm 0.02^{\mathrm{d}}$ & $0.58 \pm 0.05^{\mathrm{b}}$ & $10.87 \pm 0.37^{\mathrm{b}}$ & $18.74 \pm 2.27$ & $24.53 \pm 0.15^{4}$ \\
N30FD & $2.80 \pm 0.04^{\mathrm{e}}$ & $0.94 \pm 0.19^{\mathrm{a}}$ & $11.54 \pm 0.07^{\mathrm{a}}$ & $12.28 \pm 2.67$ & $24.95 \pm 0.21^{4}$ \\
Reconstituted FD $^{5}$ & $2.55 \pm 0.02$ & $3.86 \pm 0.13$ & $7.64 \pm 0.55$ & $1.98 \pm 0.20$ & $3.73 \pm 0.37$ \\
\hline
\end{tabular}

* Means with same letters the same column do not differ statistically $(p<0.05)$ according to Tukey's test.

${ }^{1}$ Titratable acidity, expressed as g of malic acid (main organic acid in araçá-boi (Hernández, Barrera, Martínez, \& Fernández-Trujillo, 2009)) per $100 \mathrm{~g}$ of sample; ${ }^{2}$ Total Soluble Solids, expressed as $\mathrm{g}$ of sucrose per $100 \mathrm{~g}$ of sample $\left({ }^{\circ}\right.$ Brix); ${ }^{3}$ expressed as mg per $100 \mathrm{~mL}$ of sample. ${ }^{4}$ values calculated considering the data obtained for NOFD and reconstituted FD and the proportion of each in the samples; ${ }^{5}$ reconstituted based on the moisture content of the fresh fruit (Table 1).

The $\mathrm{pH}$ of NOFD was higher (3.15) than the reconstituted FD (2.55) and, for the supplemented nectars, the $\mathrm{pH}$ decreased as the level of supplementation increased. This is in accordance to the titratable acidity behavior, which is lower for NOFD ( $0.24 \mathrm{mg}$ malic acid equiv./g) when compared to the reconstituted FD (3.86 mg malic acid equiv./g) and increases as the level of supplementation rises (Table 4). In terms of total soluble solids (TSS), it was evidenced that, as expected, higher supplementation levels resulted in higher TSS, passing from $9.85 \mathrm{~g} / 100 \mathrm{~g}$ for NOFD to $11.54 \mathrm{~g} / 100 \mathrm{~g}$ for N30FD. As for ascorbic acid content, considering that the level found for reconstituted FD $(3.73 \mathrm{mg} / 100 \mathrm{~mL})$ was much lower than that of NOFD $(24.11 \mathrm{mg} / 100 \mathrm{~mL})$, the rise of such parameter observed for the supplemented nectars was modest $(<1 \mathrm{mg} / 100 \mathrm{~mL})$ (Table 4$)$.

\subsection{Phenolic Compounds and Antioxidant Capacity}

The results obtained indicate that FD has greater amount of phenolic compounds and higher antioxidant capacity than NOFD. Therefore, the phenolic compounds and the antioxidant capacity generally increased with the increase of FD supplementation (Table 5).

In terms of total phenols, it was possible to observe an increase in this parameter as the level of supplementation increased. However, there was no significant difference between NOFD and N1FD (Table 5), which obtained the best acceptance in the sensory analysis (Table 3, Figure 1). There were also no significant differences between N1FD and N5FD, between N5FD and N10FD, and between N10FD and N15FD (Table 5). Finally, N30FD presented a level of total phenols significantly higher than all the other nectar samples (Table 5), although this one was also the sample with the lowest acceptance in sensory analysis (Table 3, Figure 1).

As for flavonoids, there were no important differences for the supplemented nectars. The highest levels of flavonoids, observed for N5FD and N30FD, were not statistically different from the levels observed for N1FD or N15FD, which, in turn, were also not statistically different from the flavonoid content of N10FD. However, the non-supplemented sample presented a level of flavonoids statistically lower than all the other nectars (Table 5).

The values obtained by the DPPH assay showed that N30FD presented the highest antioxidant capacity. Significantly lower levels were observed for N15FD or N10FD, whose values were not 
significantly different between them. The lowest antioxidant capacities for the DPPH method were observed for N0FD, N1FD and N5FD, whose values were not significantly different among them (Table 5).

Table 5. Phenolic compounds and antioxidant capacity * of non-supplemented apple nectar (NOFD), apple nectar supplemented with $1 \mathrm{~g} / \mathrm{L}$ (N1FD), 5 g/L (N5FD), $10 \mathrm{~g} / \mathrm{L}$ (N10FD), 15 g/L (N15FD) or $30 \mathrm{~g} / \mathrm{L}$ (N30FD) of freeze-dried araçá-boi and reconstituted freeze-dried araçá-boi. Three replications were performed and data are presented as mean \pm standard deviation. Values from the same column with the same superscript letter do not present statistical differences $(p<0.05)$ (FD not included).

\begin{tabular}{cccccc}
\hline Sample & Total Phenols $^{\mathbf{1}}$ & Flavonoids $^{\mathbf{3}}$ & DPPH $^{\mathbf{5}}$ & TEAC $^{\mathbf{5}}$ & ORAC $^{\mathbf{5}}$ \\
\hline N0FD & $0.374 \pm 0.012^{\mathrm{e}}$ & $1.126 \pm 0.033^{\mathrm{c}}$ & $0.142 \pm 0.021^{\mathrm{bc}}$ & $0.244 \pm 0.003^{\mathrm{d}}$ & $0.826 \pm 0.075^{\mathrm{bc}}$ \\
N1FD & $0.389 \pm 0.008^{\mathrm{de}}$ & $1.433 \pm 0.054^{\mathrm{ab}}$ & $0.126 \pm 0.003^{\mathrm{c}}$ & $0.296 \pm 0.003^{\mathrm{c}}$ & $0.718 \pm 0.024^{\mathrm{c}}$ \\
N5FD & $0.405 \pm 0.008^{\mathrm{cd}}$ & $1.522 \pm 0.067^{\mathrm{a}}$ & $0.139 \pm 0.008^{\mathrm{c}}$ & $0.286 \pm 0.003^{\mathrm{c}}$ & $0.969 \pm 0.082^{\mathrm{abc}}$ \\
N10FD & $0.419 \pm 0.007^{\mathrm{bc}}$ & $1.328 \pm 0.070^{\mathrm{b}}$ & $0.180 \pm 0.003^{\mathrm{b}}$ & $0.343 \pm 0.009^{\mathrm{b}}$ & $0.973 \pm 0.004^{\mathrm{ab}}$ \\
N15FD & $0.430 \pm 0.008^{\mathrm{b}}$ & $1.448 \pm 0.034^{\mathrm{ab}}$ & $0.188 \pm 0.013^{\mathrm{b}}$ & $0.339 \pm 0.003^{\mathrm{b}}$ & $1.163 \pm 0.056^{\mathrm{a}}$ \\
N30FD & $0.554 \pm 0.011^{\mathrm{a}}$ & $1.537 \pm 0.091^{\mathrm{a}}$ & $0.232 \pm 0.006^{\mathrm{a}}$ & $0.433 \pm 0.013^{\mathrm{a}}$ & $1.214 \pm 0.087^{\mathrm{a}}$ \\
FD & $82.32 \pm 6.31^{2}$ & $90.78 \pm 0.14^{4}$ & $30.60 \pm 0.43^{6}$ & $48.73 \pm 0.31^{6}$ & $135.31 \pm 2.40^{6}$ \\
\hline
\end{tabular}

${ }^{*}$ Means with same letters the same column do not differ statistically $(p<0.05)$ according to Tukey's test. ${ }^{1}$ expressed as $\mathrm{mg}$ gallic acid equivalents per $100 \mathrm{~g}$ of nectar $(\mathrm{fw}),{ }^{2}$ expressed as mg gallic acid equivalents per $100 \mathrm{~g}$ of fruit $(\mathrm{dw}),{ }^{3}$ expressed as mg CE per $100 \mathrm{~g}$ of nectar $(\mathrm{fw}),{ }^{4}$ expressed as mg CE per $100 \mathrm{~g}$ of fruit (dw), ${ }^{5}$ expressed as $\mu \mathrm{mol}$ TE per gram of nectar (fw), ${ }^{6}$ expressed as $\mu \mathrm{mol}$ TE per gram of fruit (dw).

As for the antioxidant capacity determined by TEAC assay, the highest level was evidenced for N30FD. A significantly lower activity was observed for N15FD and N10FD, whose values were not significantly different between them. Even lower antioxidant capacities were determined for N5FD and N1FD, these two presenting levels not statistically different between them. The lowest antioxidant capacity, statistically lower than all the other nectars, was evidenced for non-supplemented apple nectar (Table 5).

Finally, for the antioxidant capacity determined by ORAC method, the highest activities were observed, in a decreasing order, for nectars supplemented with $30 \mathrm{~g} / \mathrm{L}, 15 \mathrm{~g} / \mathrm{L}, 10 \mathrm{~g} / \mathrm{L}$ and $5 \mathrm{~g} / \mathrm{L}$ FD, whose values were not significantly different among them. Similarly, N0FD, N5FD and N10FD did not show statistically significant difference among them. The lowest antioxidant capacity was determined for N1FD, but the activity of this sample was not significantly different from N0FD or N5FD (Table 5).

\section{Discussion}

The araçá-boi used in the present paper presented a centesimal composition and physicochemical parameters generally similar to those found in former studies [17,19,34,35]. In terms of phenolic compounds and antioxidant capacity of FD, some differences were observed between this and other studies. The total phenolic compounds found here, $82.32 \mathrm{mg}$ GAE/100 $\mathrm{g}$ of fruit dw (Table 5), equivalent to $9.94 \mathrm{mg}$ GAE/100 $\mathrm{g} \mathrm{fw}$, was lower than the values reported by Garzón et al. (2012) [19] (34.1 mg GAE/100 g fw), Lizcano, Bakkali, Begoña Ruiz-Larrea, \& Ignacio Ruiz-Sanz (2010) [36] (157.00 mg GAE/100 g fw) and Neri-Numa et al. (2013) [9] (184.08 mg GAE/100 g dw), while the level of flavonoids found here (90.78 mg CE/100 g of fruit dw, equivalent to $10.96 \mathrm{mg}$ CE/100 $\mathrm{g}$ fw), was higher than that determined by Lizcano et al. (2010) [36] (5 mg CE/100 g fw). The antioxidant capacity found in the present study was also higher than those found in previous results. The antioxidant capacity by DPPH method was $30.60 \mu \mathrm{mol}(7.66 \mathrm{mg}) \mathrm{TE} / \mathrm{g}$ of fruit $\mathrm{dw}$ (Table 5), equivalent to $3.69 \mu \mathrm{mol}$ (0.92 mg) TE/g fw, while Garzón et al. (2012) [19] found $0.5 \mathrm{mg} \mathrm{TE} / \mathrm{g}$ fw. As for TEAC method, the antioxidant capacity obtained here $(48.73 \mu \mathrm{mol}(12.19 \mathrm{mg}) \mathrm{TE} / \mathrm{g}$ of fruit dw (Table 5), equivalent to $5.88 \mu \mathrm{mol}(1.47 \mathrm{mg}) \mathrm{TE} / \mathrm{g} \mathrm{fw})$ was also higher than the values reported by Garzón et al. (2012) [9] (0.65 mg TE/g fw), Canuto et al. (2010) [34] (0.75 mg TE/g fw) and Lizcano et al. (2010) [36] (1.4 mg $\mathrm{TE} / \mathrm{g} \mathrm{fw}$ ). As for the ORAC method, we obtained an antioxidant capacity of $135.3 \mu \mathrm{mol} \mathrm{TE} / \mathrm{g}$ of fruit $\mathrm{dw}$ (Table 5), equivalent to $16.33 \mu \mathrm{mol} \mathrm{TE} / \mathrm{g} \mathrm{fw}$, while Lizcano et al. (2010) [36] and Neri-Numa et al. 
(2013) [9] found an antioxidant capacity of $12.1 \mu \mathrm{mol} \mathrm{TE} / \mathrm{g}$ fw and $3.72 \mu \mathrm{mol}$ TE per g of freeze-dried ethanolic extract, respectively. It is known that the physical and chemical constitution of a given fruit is determined by an integrated effect of many factors, such as variety, weather conditions, soil, altitude, fertilization, irrigation, pests, pruning, among others [37]. This might explain some of the differences when comparing different studies. Moreover, the differences observed may find explanation in the sample preparation and methods of extraction.

Juice and fruit nectars, prepared with a blend of two or more fruits, have become a growing market segment since it can provide higher nutritional and functional benefits and new sensory characteristics [38]. For this reason, they are good candidates to be supplemented with functional ingredients, therefore increasing its health appeal to consumers [39]. In this article we evaluated how the supplementation of apple nectar with different amounts of FD could influence the consumer acceptance and the antioxidant capacity of this beverage.

In the present study, the apple nectar supplementation generally resulted in an increase (not always statistically significant) in acidity (with concomitant decrease in pH), TSS, ascorbic acid content and antioxidant capacity. On the other hand, the sensory analyses have not shown a linear behavior in terms of acceptance and level of supplementation. This might be explained in terms of TSS/Acidity ratio whose relation with acceptance usually increases up to a limit value, beyond which acceptance decreases. Regarding apple juice, a TSS/Acidity ratio of 41.89 (acidity of $0.35 \%$ and 14.66 of soluble solids) resulted in the highest acceptance among consumers [40].

Therefore, considering our objective to maximize the phenolic content and the antioxidant behavior of the nectar while keeping its sensory acceptance, one might identify an optimum supplementation level. In terms of sensory impression, the best scores among all samples in the Acceptance and Purchase Intention test was evidenced for N1FD (Table 3; Figure 1). However, this sample has not shown significant differences in terms of total phenols and antioxidant capacity (DPPH and ORAC assays) when compared to NOFD (reference nectar), although the level of flavonoids and antioxidant capacity (TEAC assay) were significantly higher (Table 5). N10FD, in turn, presented significant increase in total phenols, flavonoids and antioxidant capacity with regard to NOFD, except for ORAC assay (not statistically different from neither N0FD or the highest ORAC value, i.e., N30FD) (Table 5). Nevertheless, although enriched with phenolics and antioxidants, N10FD has not shown statistically difference in terms of acceptance (Table 3) and also presented an Purchase Intention quite similar to the reference product (NOFD) (Figure 1). This demonstrates the possibility of enhancing the nutritional quality of this nectar without interfering significantly in its sensory aspects.

\section{Conclusions}

We showed that the supplementation of commercial apple nectar with an exotic fruit from Brazil (araçá-boi), at an optimal concentration of $10 \mathrm{~g} / \mathrm{L}$, can enhance the total phenols, flavonoids and the antioxidant capacity of this beverage without significantly interfering in its sensory properties. Therefore, we cannot avoid of speculating that similar behaviors may be possible when supplementing araçá-boi (why not other fruits?) to other food preparations, such as yogurts, for which a higher acidity is not only expected but also desired, besides its antioxidant properties, considerably lower than commercial apple nectars. In such case, we envisage that the increment in antioxidant capacity would be much greater than that observed in the present study and also that the sensory acceptance could be better, even for yogurts supplemented with higher proportions of FD. Therefore, this study might serve as basis for researchers willing to increase the nutritional quality of foods and beverages by the addition fruits or fruit extracts.

Acknowledgments: The authors would like to thank National Council for Scientific and Technological Development (CNPq) (Process number: 403156/2013-1) and The São Paulo Research Foundation (FAPESP) (Process number: 2015/50333-1) for the financial support; and the Coordination for the Improvement of Higher Education Personnel (CAPES) for the scholarship (T.F. Baldini). 
Author Contributions: Iramaia Angélica Neri-Numa, Glaucia Maria Pastore and Juliano Lemos Bicas conceived and designed the experiments; Tatiana Ferrari Baldini performed the experiments; Tatiana Ferrari Baldini, Glaucia Maria Pastore and Juliano Lemos Bicas analyzed the data; Marcio Schmiele contributed with the centesimal composition analyses; Celio Kersul do Sacramento supplied the fruits and contributed with the design of the experiments; Helena Maria Andre Bolini contributed with the design of experiments and interpretation of data from the Sensory Analysis tests. Tatiana Ferrari Baldini, Iramaia Angélica Neri-Numa and Juliano Lemos Bicas wrote the paper.

Conflicts of Interest: The authors declare no conflict of interest.

\section{Abbreviations}

$\begin{array}{ll}\text { AAPH } & \text { 2,20-azobis(2-methylamidinopropane)-dihydrochloride } \\ \text { ABTS } & \text { 2,2'azino-bis-3-ethylbenzthiazoline-3-sulphonic acid } \\ \text { CE } & \text { catechin equivalent } \\ \text { DPPH } & \text { 2,2-difenil-1-picrilhidrazila } \\ \text { FD } & \text { freeze-dried araçá-boi } \\ \text { GAE } & \text { gallic acid equivalent } \\ \text { NOFD } & \text { non-supplemented (pure) apple nectar } \\ \text { N1FD } & \text { apple nectar supplemented with } 1 \mathrm{~g} / \mathrm{L} \text { of freeze-dried araçá-boi } \\ \text { N5FD } & \text { apple nectar supplemented with } 5 \mathrm{~g} / \mathrm{L} \text { of freeze-dried araçá-boi } \\ \text { N10FD } & \text { apple nectar supplemented with } 10 \mathrm{~g} / \mathrm{L} \text { of freeze-dried araçá-boi } \\ \text { N15FD } & \text { apple nectar supplemented with } 15 \mathrm{~g} / \mathrm{L} \text { of freeze-dried araçá-boi } \\ \text { N20FD } & \text { apple nectar supplemented with } 20 \mathrm{~g} / \mathrm{L} \text { of freeze-dried araçá-boi } \\ \text { N30FD } & \text { apple nectar supplemented with } 30 \mathrm{~g} / \mathrm{L} \text { of freeze-dried araçá-boi } \\ \text { TE } & \text { Trolox equivalent } \\ \text { TEAC } & \text { Trolox equivalent antioxidant capacity } \\ \text { Trolox } & \text { 6-hydroxy-2,5,7,8-tetramethylchromane-2-carboxylic acid. }\end{array}$

\section{References}

1. Nayak, B.; Liu, R.H.; Tang, J. Effect of Processing on Phenolic Antioxidants of Fruits, Vegetables, and Grains-A Review. Crit. Rev. Food Sci. Nutr. 2015, 55, 887-918. [CrossRef] [PubMed]

2. Da Silva, L.M.R.; De Figueiredo, E.A.T.; Ricardo, N.M.P.S.; Vieira, I.G.P.; De Figueiredo, R.W.; Brasil, I.M.; Gomes, C.L. Quantification of bioactive compounds in pulps and by-products of tropical fruits from Brazil. Food Chem. 2014, 143, 398-404. [CrossRef] [PubMed]

3. Kabir, F.; Tow, W.W.; Hamauzu, Y.; Katayama, S.; Tanaka, S.; Nakamura, S. Antioxidant and cytoprotective activities of extracts prepared from fruit and vegetable wastes and by-products. Food Chem. 2015, 167, 358-362. [CrossRef] [PubMed]

4. Neves, L.C.; Tosin, J.M.; Benedette, R.M.; Cisneros-Zevallos, L. Post-harvest nutraceutical behaviour during ripening and senescence of 8 highly perishable fruit species from the Northern Brazilian Amazon region. Food Chem. 2015, 174, 188-196. [CrossRef] [PubMed]

5. Shahidi, F.; Ambigaipalan, P. Phenolics and polyphenolics in foods, beverages and spices: Antioxidant activity and health effects-A review. J. Func. Foods 2015, 18, 820-897. [CrossRef]

6. Araújo, J.R.; Martins, M.R. Fruteiras nativas: Ocorrência e potencial de utilização na agricultura familiar do Maranhão. In Agroambientes de Transição Entre o Trópico Úmido e Semi-Árido Maranhense, 1st ed.; Moura, E.G., Ed.; UEMA: São Luís, Brasil, 2004; pp. 257-312.

7. Rufino, M.S.M.; Alves, R.E.; de Brito, E.S.; Pérez-Jiménez, J.; Saura-Calixto, F.; Mancini-Filho, J. Bioactive compounds and antioxidant capacities of 18 non-traditional tropical fruits from Brazil. Food Chem. 2010, 121, 996-1002. [CrossRef]

8. Omena, C.M.B.; Valentim, I.B.; Guedes, G.S.; Rabelo, L.A.; Mano, C.M.; Bechara, E.J.H.; Goulart, M.O.F. Antioxidant, anti-acetylcholinesterase and cytotoxic activities of ethanol extracts of peel, pulp and seeds of exotic Brazilian fruits. Antioxidant, anti-acetylcholinesterase and cytotoxic activities in fruits. Food Res. Int. 2012, 49, 334-344. [CrossRef] 
9. Neri-Numa, I.A.; Carvalho-Silva, L.B.; Morales, J.P.; Malta, L.G.; Muramoto, M.T.; Ferreira, J.E.M.; Pastore, G.M. Evaluation of the antioxidant, antiproliferative and antimutagenic potential of araçá-boi fruit (Eugenia stipitata Mc Vaugh-Myrtaceae) of the Brazilian Amazon Forest. Food Res. Int. 2013, 50, 70-76. [CrossRef]

10. Pereira, M.C.; Steffens, R.S.; Jablonski, A.; Hertz, P.F.; Rios, A.O.; Vizzotto, M.; Flores, S.H. Characterization, bioactive compounds and antioxidant potential of three Brazilian fruits. J. Food Compos. Anal. 2013, 29, $19-24$. [CrossRef]

11. Bhardwaj, R.L.; Pandey, S. Juice Blends-A Way of Utilization of Under-Utilized Fruits, Vegetables, and Spices: A Review. Crit. Rev. Food Sci. Nutr. 2011, 51, 563-570. [CrossRef] [PubMed]

12. Boghani, A.H. Development and storage studies of blended papaya-aloe vera ready to serve (RTS) beverage. J. Food Proc. Technol. 2012, 3. [CrossRef]

13. De Souza Filho, M.S.M.; Lima, J.R.; Nassu, R.T.; Moura, C.F.H.; Borges, M.D.F. Formulações de néctares de frutas nativas das regiões norte e nordeste do Brasil. Bol. CEPPA 2000, 18, 275-283. [CrossRef]

14. Viana, E.S.; Jesus, J.L.; Reis, R.C.; Andrade, M.V.S.; Sacramento, C.K. Physicochemical and Sensory Characterization of Banana and Araçá-Boi Jam. Food Nutr. Sci. 2014, 5, 733-741. [CrossRef]

15. Kumar, B.; Smita, K.; Debut, A.; Cumbal, L. Extracellular green synthesis of silver nanoparticles using Amazonian fruit Araza (Eugenia stipitata McVaugh). Trans. Nonferrous Met. Soc. China 2016, 26, 2363-2371. [CrossRef]

16. Franco, M.R.B.; Shibamoto, T. Volatile composition of some brazilian fruits: Umbu-caja (Spondias citherea), camu-camu (Myrciaria dubia), araca-boi (Eugenia stipitata), and cupuacu (Theobroma grandiflorum). J. Agric. Food Chem. 2000, 48, 1263-1265. [CrossRef] [PubMed]

17. Rogez, H.; Buxant, R.; Mignolet, E.; Souza, J.N.S.; Silva, E.M.; Larondelle, Y. Chemical composition of the pulp of three typical Amazonian fruits: Araça-boi (Eugenia stipitata), bacuri (Platonia insignis) and cupuaçu (Theobroma grandiflorum). Eur. Food Res. Technol. 2004, 218, 380-384. [CrossRef]

18. Reynertson, K.A.; Basile, M.J.; Kennelly, E.J. Antioxidant Potential of Seven Myrtaceous Fruits. Ethnobot. Res Appl. 2005, 3, 25-35. [CrossRef]

19. Garzón, G.A.; Narváez-Cuenca, C.E.; Kopec, R.E.; Barry, A.M.; Riedl, K.M.; Schwartz, S.J. Determination of carotenoids, total phenolic content, and antioxidant activity of Arazá (Eugenia stipitata McVaugh), an Amazonian fruit. J. Agric. Food Chem. 2012, 60, 4709-4717. [CrossRef] [PubMed]

20. De Souza Schmidt Gonçalves, A.E.; Lajolo, F.M.; Genovese, M.I. Chemical composition and antioxidant/antidiabetic potential of Brazilian native fruits and commercial frozen pulps. J. Agric. Food Chem. 2010, 58, 4666-4674. [CrossRef] [PubMed]

21. Association of Official Analytical Chemists (AOAC). Official Methods of Analysis of AOAC International. In Association of Official Analysis Chemists International, 19th ed.; AOAC International: Gaithersburg, ML, USA, 2012.

22. Anvisa. RESOLUÇÃO RDC N $\mathrm{N}^{\circ}$ 360, DE 23 DE DEZEMBRO DE 2003. 2003. Available online: http:/ / portal.anvisa.gov.br/documents/33880/2568070/res0360_23_12_2003.pdf/5d4fc713-9c664512-b3c1-afee57e7d9bc (accessed on 10 August 2015).

23. Instituto Adolf Lutz. Métodos Físicos-Quimicos Para Análise de Alimentos, 4th ed.; SES-CCD—IAL: São Paulo, Brasil, 2008; pp. 589-625.

24. Meilgaard, M.; Civille, G.; Carr, T. Sensory Evaluation Techniques, 3rd ed.; CRC Press: New York, NY, USA, 2004.

25. Macfie, H.J.; Bratchell, N.; Greenhoff, K.; Vallis, L.V. Designs to balance the effect of order of presentation and first-order carry-over effects in hall tests. J. Sens. Stud. 1989, 4, 129-148. [CrossRef]

26. Dutcosky, S. Análise Sensorial de Alimentos, 3rd ed.; Champagnat: Curitiba, Brasil, 2011.

27. Stone, H.; Bleibaum, R.; Thomas, H.A. Sensory Evaluation Practices, 4th ed.; Elsevier Academic Press: San Diego, CA, USA, 2012.

28. Stone, H.; Sidel, J.L. Sensory Evaluation Practices, 3rd ed.; Academic Press: Cambridge, CA, USA, 2004.

29. Roesler, R. Estudo de Frutas do Cerrado Brasileiro para Avaliação de Propriedade Funcional com Foco na Atividade Antioxidante. Ph.D. Thesis, Universidade Estadual de Campinas, Campinas, Brazil, 2007.

30. Jia, Z.; Tang, M.; Wu, J. The determination of flavonoid contents in mulberry and their scavenging effects on superoxide radicals. Food Chem. 1999, 64, 555-559. [CrossRef]

31. Scherer, R.; Godoy, H.T. Antioxidant activity index (AAI) by the 2,2-diphenyl-1-picrylhydrazyl method. Food Chem. 2009, 112, 654-658. [CrossRef] 
32. Re, R.; Pellegrini, N.; Proteggente, A.; Pannala, A.; Yang, M.; Rice-Evans, C. Antioxidant activity applying an improved ABTS radical cation decolorization assay. Free Radic. Biol. Med. 1999, 26, 1231-1237. [CrossRef]

33. Leite, A.V.; Malta, L.G.; Riccio, M.F.; Eberlin, M.N.; Pastore, G.M.; Maróstica Júnior, M.R. Antioxidant potential of rat plasma by administration of freeze-dried jaboticaba peel (Myrciaria jaboticaba Vell Berg). J. Agric. Food Chem. 2011, 59, 2277-2283. [CrossRef] [PubMed]

34. Canuto, G.A.B.; Xavier, A.A.O.; Neves, L.C.; Benassi, M.D.T. Caracterização físico-química de polpas de frutos da Amazônia e sua correlação com a atividade anti-radical livre. Rev. Bras. Frutic. 2010, 32, 1196-1205. [CrossRef]

35. Sacramento, C.K.; Barretto, W.S.; Faria, J.C. Araçá-boi: Uma alternativa para agroindústria. Bahia Agrícola 2008, 8, 22-24.

36. Lizcano, L.J.; Bakkali, F.; Begoña Ruiz-Larrea, M.; Ignacio Ruiz-Sanz, J. Antioxidant activity and polyphenol content of aqueous extracts from Colombian Amazonian plants with medicinal use. Food Chem. 2010, 119, 1566-1570. [CrossRef]

37. Nascimento, V.E. Caracterização de Plantas de Mamey. Master's Thesis, Universidade Estadual Paulista, Jaboticabal, Brazil, 2008.

38. Morzelle, M.C.; Souza, E.C.; Assumpção, C.F.; Flores, J.C.J.; Oliveira, K.A.M. Agregação de valor a frutos de ata através do desenvolvimento de néctar misto de maracujá (Passiflora edulis Sims) e ata (Annona squamosa L.). Aliment. Nutr. Araraquara 2009, 20, 389-393.

39. Martínez-Sánchez, A.; Alacid, F.; Rubio-Arias, J.A.; Fernández-Lobato, B.; Ramos-Campo, D.J.; Aguayo, E. Consumption of Watermelon Juice Enriched in 1 -Citrulline and Pomegranate Ellagitannins Enhanced Metabolism during Physical Exercise. J. Agric. Food Chem. 2017, 65, 4395-4404. [CrossRef] [PubMed]

40. Jorge, Z.L.C.; Treptow, R.O.; Antunes, P.L. Avaliação físico-química e sensorial de suco de maçãs cultivares Fuji, Granny Smith e seus “blends”. Rev. Bras. Agrociênc. 1998, 4, 15-19. [CrossRef]

(C) 2017 by the authors. Licensee MDPI, Basel, Switzerland. This article is an open access article distributed under the terms and conditions of the Creative Commons Attribution (CC BY) license (http:/ / creativecommons.org/licenses/by/4.0/). 